\title{
Konstruksi Etis Teologis tentang Investasi Keuangan Gereja: Analisis Lukas 19:16-24
}

Theological Ethical Construction on the Church Financial Investment: Analysis Luke 19:16-24

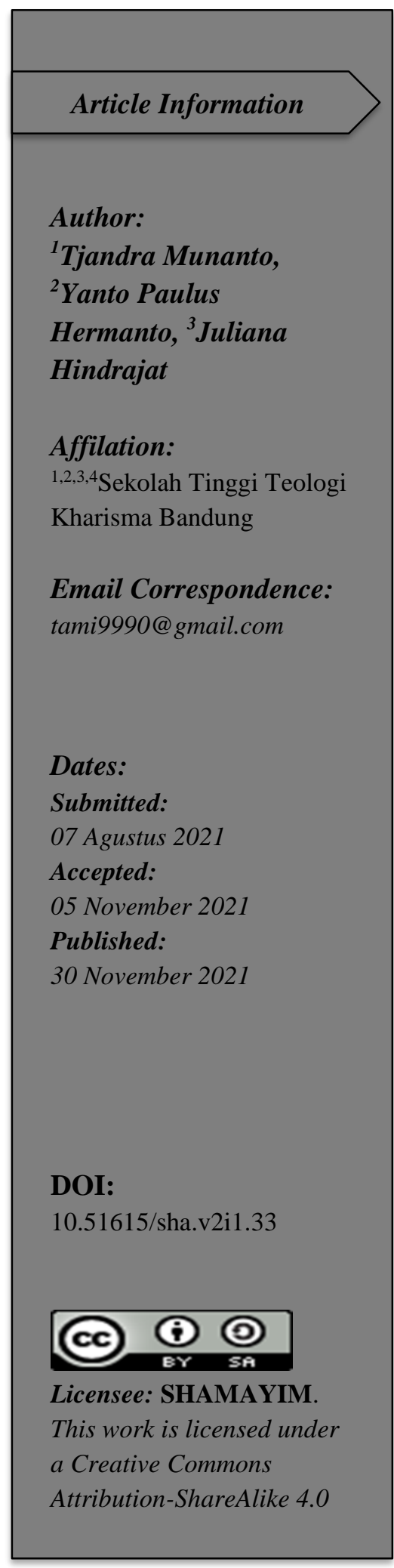

Abstract: The church as a non-profit organization has a vision and mission related to effective fund management. Considering recent developments where the church is being challenged to face various world problems such as natural disasters, economic crises, pandemics, lack of funds, world inflation, the church must find a way out so that all the main activities of the church can run well. One of the most important factors in managing church funds is how the church can find alternative sources of income so that church funds do not depend solely on the congregation's love offerings and the congregation's tithe which tends to be increasingly uncertain in number. To answer the research problem, the author uses a qualitative research approach and through excavation of Luke 19:12-27. The purpose of this research is to provide a way out for churches in managing church funds. From the results of this study obtained a biblical method of investment, effective and low risk level.

\section{Keywords: Church Mission, Finance, Financial Management, Investment}

Abstrak: Gereja sebagai organisasi non-profit memiliki visi dan misi yang berkaitan dengan pengelolaan dana yang efektif. Mengingat perkembangan akhir-akhir ini dimana gereja ditantang menghadapi berbagai permasalahan dunia seperti bencana alam, krisis ekonomi, pandemi, kekurangan dana, inflasi dunia, maka gereja harus mencari jalan keluar agar seluruh kegiatan utama gereja dapat berjalan dengan baik. Salah satu faktor yang terpenting dalam mengelola dana gereja adalah bagaimana gereja dapat mencari sumber pendapatan alternatif agar dana gereja tidak semata-mata tergantung kepada persembahan kasih jemaat dan persepuluhan jemaat yang cenderung makin tidak menentu jumlahnya. Untuk menjawab permasalah penelitian maka penulis menggunakan pendekatan penetian kualitatif dan melalui penggalian terhadap Lukas 19:12-27. Tujuan penelitian ini untuk memberikan jalan keluar bagi gereja-gereja dalam mengelola dana gereja. Dari hasil penelitian ini diperoleh cara inestasi yang alkitabiah, efektif dan tingkat resiko yang rendah.

Kata Kunci: Misi Gereja, Keuangan, Manajemen Keuangan, Investasi. 


\section{Pendahuluan}

Pengelolaan dana suatu perusahaan atau organisasi merupakan suatu hal yang sangat penting untuk mencapai tujuan akhir dari perusahaan atau organisasi tersebut. Keberhasilan suatu organisasi memang bukan sepenuhnya ditentukan dengan keberhasilan pengelolaan dana, namun pengelolaan dana memegang peranan seperti suatu jantung dalam sistem tubuh manusia. Jantung mengelola darah dalam tubuh dan membawa oksigen menuju seluruh jaringan tubuh manusia agar bisa bekerja dan bergerak, demikian pula pengelolaan dana adalah mengelola dana yang ada didistribusikan kepada departemen-departemen suatu organisasi agar organisasi ini bisa menjalankan visi dan misi agar tercapai dengan baik.

Pengelolaan dana gereja yang baik, dilakukan dengan transparan atau terbuka sehingga menjadi jelas bagi semua jemaat (Raya, 2017). Keterbukaan laporan keuangan organisasi keagamaan sangatlah penting. Terlebih lagi, stakeholder dari organisasi menekankan pentingnya pelaksanaan prinsip-prinsip corporate governance (GCG), yang menurut Organization for Economic Co-operation and Development meliputi fairness, transparency, accountability and responsibility (Randa, 2011). Selain harus transparan, pengelolaan dana gereja juga harus tercatat dengan baik sebagai bentuk tanggung jawab atas dana gereja yang didapat dari jemaat. Jadi, Accountability adalah perwujudan kewajiban-kewajiban otoritas yang dipercayakan untuk dikelola sebagai bentuk pertanggungjawaban atas bagaimana hasilnya, bisa berhasil atau gagal dan menjelaskan pelaksanaan yang dilakukan apakah sesuai dengan misi organisasi (Silvia \& Ansar, 2011).

Ada beberapa kasus yang beredar di media massa tentang adanya penyelewengan penggunaan dana gereja oleh oknum pendeta atau majelis gereja (Faizal, 2013). Hal ini terjadi karena dana-dana yang terkumpul di gereja adalah sumbangan sehingga tidak dapat dituntut pertanggungjawabannya oleh jemaat. Menurut penelitian yang ada insiden fraud di dalam organisasi gereja meningkat sangat pesat dengan peningkatan kasus mendekati sekitar 6\% setiap tahunnya. Dengan demikian, pengelolaan dana gereja yang transparan dan akuntabel sangatlah penting dalam mempertanggungjawabkan keuangan dan hal ini dapat meningkatkan kepercayaan jemaat, sehingga diharapkan bisa meningkatkan dana yang jemaat sumbangkan kepada gereja untuk menjalankan misi gereja tersebut.

Sebagian besar gereja-gereja yang berdiri saat ini sangat mengandalkan pendapatan dana gereja dari hasil persembahan kasih dan persepuluhan jemaat, sehingga salah satu kendala terbesar dalam menjalankan misi gereja adalah ketergantungan terhadap donasi dari orang lain (Alawode, 2020), di mana sumber pendapatan ini tidak menentu jumlahnya setiap bulannya. Di sisi lain, biaya yang diperlukan oleh gereja untuk menjalankan operasional kegiatan gereja dan misi gereja makin lama makin meningkat seiring dengan peningkatan aktifitas yang dikembangkan untuk memenuhi kebutuhan dan tuntutan pelayanan yang dibutuhkan oleh jemaat. Hal ini menyebabkan jumlah dana yang tersedia tidak menentu untuk menjaga kesinambungan kegiatan gereja untuk melanjutkan misinya dalam melayani masyarakat (Gannon \& Schwartz, 1992).

Gereja-gereja yang masih kecil yang belum bisa mencukupi biaya operasional mencari jalan untuk pemenuhan kebutuhan operasionalnya. Hal ini mengakibatkan para pendeta dari gereja ini dengan terpaksa bekerja sampingan untuk menyambung hidupnya juga keluarganya, juga dilakukan oleh Paulus bekerja sebagai tukang kemah dan setiap hari Sabat berbicara dalam rumah ibadat dan berusaha menyakinkan orang-orang Yahudi dan orang-orang Yunani (Kis 18: 3-4).

Pada masa ini, ada banyak penawaran investasi yang ditawarkan kepada masyarakat luas namun tidak mudah bagi gereja untuk masuk dalam investasi ini mengingat gereja harus mempertimbangkan apakah investasi ini dijalankan sesuai dengan etika alkitabiah. Bahkan Menurut berita BBC news - Indonesia 
adanya pendeta Gereja yang melakukan penggelapan dana gereja dengan membuat investasi palsu (BBC News Indonesia, 2015).

Berdasarkan uraian tersebut maka sudah sepantasnya gereja mencari sumber pendapatan lain diluar persembahan kasih dan persepuluhan jemaat untuk menjaga kelangsungan hidup gerejanya. Untuk itu maka rumusan masalah penelitian karya tulis ilmiah ini adalah: Bolehkah dana gereja diinvestasikan? Jika boleh, bagaimana caranya? Penelitian ini berbeda dengan penelitian sebelumnya yang hanya membahas mengenai penentuan dana pensiun gereja di gereja tertentu (Sinay et al., 2018), dan mengenai Paulus sang entepreneur (Silalahi, 2019). Kedua penelitian tersebut lebih menekankan pada dana pensiun bagi para pendeta dan bagaimana Paulus sebagai Rasul mencukupi dirinya sendiri melalui usaha Kemah dan tidak membahas bagaimana mengelola dana gereja dalam bentuk investasi yang baik. Tujuan penelitian ini adalah bisa menjawab bagaimana sebaiknya dana gereja diinvestasikan dan bagaimana cara-cara investasi seharusnya yang sesuai Alkitab. Dengan demikian gereja dalam kondisi pandemi sekalipun tetap bisa berjalan dengan baik dan Tuhan tidak dipermalukan.

\section{Metode Penelitian}

Pendekatan yang digunakan dalam penelitian ini adalah penelitian kualitatif dengan metode deskriptif analisis maupun metode interpretasi, melalui data pustaka. Dalam penulisan ini digunakan sumber-sumber lain berupa wawancara dari orang-oang yang memahami pengelolaan dana secara alkitabiah dan memahami konsep alkitabiah yang berkaitan dengan isu ini sehingga gagasan yang dikemukakan memiliki landasan teologis alkitabiah. Hasil analisis terhadap sumber-sumber tersebut kemudian penulis sajikan secara deskriptif, sehingga akan menjawab rumusan masalah penelitian ini. Penulis juga melakukan metode interpretasi terhadap Lukas 19:16-24. Diharapkan dari interpretasi terhadap Lukas 19:16-24 dapat diperoleh tuntunan berkaitan dengan bagaimana dana gereja bisa diinvestasikan dengan baik dan efektif.

\section{Hasil dan Pembahasan}

\section{Pengelolaan Keuangan Gereja menurut Lukas 19:12- 27}

Dalam Lukas 19:12-27 merupakan perumpamaan yang disampaikan oleh Tuhan Yesus kepada orangorang di Yerikho setelah bertemu dengan Zakheus. Yesus mengawali perumpamaan ini dengan menyampaikan bahwa ada seorang bangsawan yang akan berangkat ke suatu negeri yang jauh untuk dinobatkan sebagai raja di tempat tersebut. Bangsawan ini memanggil sepuluh orang hambanya dan memberikan kepada masing-masing satu mina. Dan bangsawan ini meminta mereka mengelola yang satu mina ini sehingga bertambah. Dan mereka diminta mengelolanya hingga dia datang kembali. Meskipun orang-orang sebangsanya tidak menginginkan bangsawan ini menjadi raja dan melakukan interpelasi, namun tetap akhirnya bangsawan ini menjadi raja. Ketika sudah dinobatkan sebagai raja, bangsawan ini kembali ke tempatnya, dan memanggil hamba-hambanya yang telah menerima satu mina. Dan dari sepuluh hamba tersebut ada tiga kelompok atau tiga jenis hamba dalam menjalankan tugasnya. Kelompok satu menghasilkan jumlah mina yang fantastis yakni 10 mina, ada yang menghasilkan menengah yakni 5 mina dan ada kelompok yang tidak melakukan apa-apa dengan mina yang dititipkan tersebut.

Matthew Henry menafsirkan bahwa bangsawan yang dimaksud dalam perumpamaan itu adalah Yesus yang dinobatkan jadi Raja dan akan datang kembali untuk menghakimi. Sedangkan hamba-hamba tersebut adalah orang-orang percaya atau murid-murid-Nya yang harus mengerjakan bagian mereka dengan sebaik mungkin untuk melaksanakan misi dari Yesus (Henry, 1706, Luk.19:12-27). Hamba-hamba-Nya ini 
dibekali masing-masing satu mina (setara dengan 100 dinar) dan mereka diminta untuk berdagang dengan modal satu mina tersebut. Ada tiga tipe hamba yang diberikan uang mina oleh Tuhan, dalam hal ini Yesus Kristus ingin memberitahukan kepada para rasul maupun pengikutnya bahwa mereka tidak menjadi penguasa dan mendapat keistimewaan melainkan menjadikan mereka pengelola yang diharapkan mereka dapat mengupayakan modal berupa mina dalam melayani-Nya dan untuk kepentingan kerajaan-Nya. Hal ini merupakan suatu kehormatan bagi seorang pengikut setia Kristus yang tekun, kudus dan lebih mengutamakan untuk maksud-maksud kerajaan Allah.

Hamba pertama menghasilkan sepuluh mina dari satu mina yang diberikan tuannya. Oleh karena itu, tuannya memberikan hamba tersebut kekuasaan atas sepuluh kota. Hamba kedua melipatgandakan mina yang diberikan kepadanya menjadi lima mina dan hasilnya, dia diberikan kuasa akan lima kota, ini menggambarkan bahwa masing-masing gereja Tuhan baik secara organisasi maupun organisme diberikan satu mina (kepercayaan untuk mengelola yang dipercayakan Tuhan). Mereka diberi kepercayaan yang sama termasuk dalam mengelola keuangan gereja. Makna dari perumpamaan ini adalah Allah mau gereja-Nya berusaha semaksimal mungkin atas harta yang dipercayaan oleh-Nya tersebut untuk digunakan dalam pekerjaan-Nya di bumi (Henry, 1706). Gereja sebaiknya bisa menjalankan apa yang dipercayakan sehingga bisa berlipat ganda dan tentunya dimanfaatkan semaksimal mungkin untuk menjalankan misi sesuai kehendak-Nya.

Orang-orang yang dipercaya ini diberikan modal kecil agar mereka bekerja, mengalami banyak perjuangan untuk menghasilkan sesuatu dari apa yang mereka miliki dan untuk tujuan tertentu. Pengelolaan tersebut tentu dimaksudkan untuk memberitakan kabar baik, untuk mendirikan jemaat bagi Kristus di dunia dan menggembalakannya. Mereka memiliki pertanggungjawaban yang harus mereka laporkan, mereka dipanggil kehadapan-Nya untuk menunjukkan hasil kerja mereka atas karunia yang telah dipercayakannya dan untuk mengetahui berapa hasil dagang mereka masing-masing. Hasil yang dicapai oleh masing-masing tidaklah sama, orang yang satu memperoleh keuntungan sepuluh mina sedangkan yang lain hanya lima mina. Tentu hal ini menunjukkan bahwa mereka yang berusaha lebih keras dan lebih tekun dalam pekerjaanya menjadi penentunya (Susanto, 2019). Namun demikian Tuhan tidak melihat seberapa banyak hasilnya karena apapun hasilnya tetap Tuhan memberikan penghargaan. Dalam hal ini Tuhan menilai ketaatan, kesetiaan dan tanggung jawab dalam mengembangkan mina yang dipercayakan sesuai kesanggupan dan kemampuan masing-masing.

Semua pengikut Kristus diberikan kepercayaan walau sekecil apapun. Dan karunia yang diterima, harus digunakan semaksimal mungkin. Gereja seharusnya taat dan setia untuk mengelola apa yang dipercayakan tersebut dengan bertanggung jawab. Tuhan Yesus berkata bahwa jika seseorang setia dan bertanggung jawab dalam perkara kecil akan menerima kepercayaan yang lebih besar dalam kerajaan Allah (Guy, 1997). Bagaimana pun semua keberhasilan yang diperoleh bukan semata-mata hasil kerja keras melainkan karena kasih karunia Allah. Seperti yang dinyatakan oleh Paulus dalam 1 Korintus 15:10, bahwa meskipun Paulus sudah bekerja keras namun semuanya karena kasih karunia Allah.

Perumpamaan tentang mina menyatakan kepada gereja-Nya bahwa Tuhan mengetahui persis kemampuan setiap orang dan gerejanya. Oleh sebab itu yang Tuhan lihat adalah usaha dan kemauan untuk menjalankan dana (mina) yang diperoleh secara maksiman dan bertanggung jawab. Dan Raja pun mengapresiasi apa yang telah dilakukan orang-orang yang menjalankan dana yang dipercayakan-Nya.. Dia menginginkan anak-anak-Nya bekerja keras untuk mengelola apa yang dipercayakan tersebut dengan bertanggung jawab dan menghasilkan sesuai kemampuannya. Demikian pula dengan dana gereja diharapkan dapat dikelola dengan baik sehingga bisa lebih maksimal dalam menunjang tujuan Allah 
terhadap gereja-Nya. Besar kecil dana yang dipercayakan tidak menjadi masalah, yang penting mereka bekerja keras meskipun mengalami banyak perjuangan untuk menghasilkannya.

Hamba ketiga dalam perumpamaan mina ini tidak melakukan apa-apa dengan mina yang diberikan oleh tuannya. Hamba tersebut menyimpan mina dalam sapu tangan karena dia takut akan tuannya yang menurutnya seseorang yang keras dan akan mengambil sesuatu yang bukan miliknya. Hal ini menunjukkan bahwa hamba tersebut memiliki prasangka yang keliru dan pemalas. Mereka yang mendapatkan karunia namun tidak berusaha menggunakan dengan baik maka orang tersebut digambarkan seperti orang yang tidak menjalankan uang mina tersebut. Mereka tidak mau bersusah payah, tidak mau kehilangan apapun dan merasa cukup dengan keadaanya yang sekarang yang penting tidak membawa kerugian apapun di dunia ini. Tidak demikian dengan pengikut Kristus dituntut untuk peduli dan tidak boleh malas dalam berusaha untuk mengelola apa yang telah dipercayakan, terus memberitakan Kerajaan Allah dan membawa lebih banyak orang kepada-Nya. Demikian pula dengan dana gereja yang dipercayakan tidak boleh disimpan dan tidak dimanfaatkan untuk menghasilkan lebih banyak manfaat bagi pelayanan gereja terutama terhadap umat-Nya. Setiap pengurus gereja baik pendeta maupun majelis gereja wajib bersyukur atas dana gereja yang mereka miliki dan mempunyai kewajiban untuk mengembangkan dana gereja tersebut dengan baik agar dapat menghasilkan maksimal untuk menggerakkan roda pelayanan gereja.

\section{Pandangan Dari Beberapa Sumber Lain Berkaitan Dengan Dana Gereja}

Untuk lebih mendalami investasi atau usaha untuk mendapatkan untung, ada beberapa pandangan yang bisa menjadi dasar berinvestasi yang tepat. Pandangan Martin Luther berkaitan dengan hal ini adalah sebagai berikut: "This is why no one need ask how he may with a good conscience be a member of trading company. My only advice is this: Get out; they will not change. If the trading companies are to stay, right and honesty must perish; if right and honesty are to stay, the trading companies must perish")(Luther \& Carruth, 1897).

Di sisi lain, dari pandangan Calvin, dia mengakui dunia perdagangan yang berkembang sebagai suatu arena kegiatan yang sah bagi seorang Kristen, dan ini berkaitan erat dengan arah panggilan yang diterima dalam Protestanisme Reformasi. Secara khusus Calvin membaca perumpamaan tentang talenta yang similar dengan Lukas 19:16-24 (Mat. 25: 14 - 30) dalam pengertian yang lebih harafiah sebagai penatalayanan ekonomi. Sebagai contoh, Calvin menerangkan bahwa kalau memberi pinjaman untuk menikmati bunga (riba) dianggap sebagai perbuatan jahat yang setara dengan membunuh, maka memberi pinjaman untuk produksi dan usaha dengan bunga yang rendah dapat diterima (WF Graham, 1971). Dari pandangan Martin Luther diatas kita dapat menyimpulkan bahwa semua usaha harus dilakukan dengan hati nurani yang murni. Sedangkan menurut pandangan Calvin, bisa simpulkan semua usaha adalah sah bila dilakukan dengan motivasi membantu orang lain atau tidak merugikan orang lain.

Dari hasil wawancara dengan Dr. Chris Adrian (Adrian, Chris.Dr ( Lecturer in Accounting, n.d.), dijelaskan sebagai berikut: Organisations, including both profit and non-profit, engage in investment in order to generate returns in sustaining their financial stability. There are a few factors that organisations need to consider in making investment decisions, including but are not limited to, risk management, tradeoff between potential risk and rewards related to the investments, and the type of investments.

Jadi jelas bahwa tujuan investasi adalah untuk mencari keuntungan dengan resiko investasi yang ada, dimana menurut Dr. Chris Adrian (Adrian, Chris.Dr ( Lecturer in Accounting, n.d.): Risks associated with investments can be classified into (i) systematic risk and (ii) unsystematic risk. Systematic risk is the risk 
that is related to the whole market/economy, such as interest rate change, inflation, and global economic crisis. On the other hand, unsystematic risk is the risk that is inherent to particular firms/industries and largely unrelated to the whole market

Banyak studi di literatur yang menyelidiki strategi-strategi yang dapat ditempuh oleh penanam modal untuk meminimalisir unsystematic risk (Aggarwal \& Samwick, 2003). Dengan konsep yang sama, penanam modal juga dapat menggunakan strategi ini dan mempunyai diversifikasi portfolio untuk melindungi mereka dari resiko ini.

\section{Sasaran Investasi Dana Gereja adalah Misi}

Salah satu misi utama gereja adalah bagaimana meningkatkan peran misi jemaat (yanto Paulus Hermanto, 2021). Misi ini seharusnya menjadi fokus utama dari gereja, karena dengan menumbuhkan rohani dan peran misi jemaat, maka gereja akan bertumbuh dan bisa melaksanakan amanat agung Kristus. Tentu untuk mencapai misi ini perlu perencanaan, sumberdaya dan kemampuran finansial yang memadai.

Kesinambungan misi gereja secara keseluruhan sangat tergantung dengan dana yang tersedia. Di sisi lain budaya masyarakat saat ini masih mempunyai pandangan bahwa gereja hanya fokus kepada pelayanan dan penyerahan kepada Tuhan saja. Segala jenis usaha maupun investasi yang menyangkut uang masih dianggap tabu dan diduga akan menyesatkan karena gereja dinilai lebih mementingkan uang atau mengejar keuntungan semata. Hal ini disangkakan sebagai organisasi yang mencintai dan terlalu mengejar uang seperti yang disampaikan Paulus kepada Timotius (1 Tim. 6:10). Sehingga dikuatirkan akan jatuh ke dalam berbagai pencobaan atau kesulitan.

Seperti yang diketahui, kemampuan gereja untuk menjalankan misi utama dalam mengabarkan injil memerlukan dana yang tidak sedikit dan tanpa adanya dana, gereja tidak bisa bergerak bagaikan sebuah kendaraan yang memerlukan bensin untuk menjalankan motor kendaraan tersebut. Dengan kenyataan yang dihadapi ini, maka sudah seharusnya semua pendeta maupun majelis gereja untuk mulai mengubah cara berpikir dan mengubah pandangan bahwa dana gereja hanya mengandalkan dana dari jemaat, melainkan bagaimana mengusahakan dana secara mandiri agar misi dan visi gereja bisa tercapai dengan baik (Alawode, 2020).

\section{Investasi Dana Gereja}

Dana gereja adalah uang yang dikumpulkan oleh gereja sebagai pendapatan gereja, yang pada umumnya didapat dari persembahan jemaat dan wajib digunakan untuk kepentingan mencapai visi dan misi gereja. Dalam tata kelola gereja, secara umum, dana gereja dicatat dan disimpan di bank oleh seorang bendahara bersama dengan pendeta dan majelis gereja. Pengelola dana gereja harus memperhatikan perencanaan, pengelolaan, pengendalian dan pelaporan yang baik dan akurat, sehingga dengan demikian dapat membangun kepercayaan dari jemaat. Lukas mengatakan dalam pasal 16: 10 - 13, bahwa pengaturan uang yang baik merupakan syarat utama yang dipakai Tuhan untuk mempercayakan perkara-perkara besar Dengan demikian gereja harus memikirkan pengelolaan dana gereja ini secara profesional dan alkitabiah. Gereja yang hanya mengandalkan sumber pendapatan dari persembahan kasih jemaat dan persepuluhan jemaat harus mulai memikirkan dengan seksama pengelolaannya, mengingat pendapatan dari persembahan kasih jemaat dan persepuluhan jemaat jumlahnya tidak pasti sehingga ada kemungkinan visi dan misi gereja tidak bisa terlaksana dengan baik.

Tata kelola keuangan gereja harus mulai membuat posting biaya yang perlu dikeluarkan sehingga benar-benar bisa melaksanakan pengelolaan dana keuangan gereja secara mandiri. Kemandirian dalam 
bidang dana harus dapat dipahami sebagai kemampuan gereja untuk menggali sumber-sumber kekayaan untuk mengamankan, melipatgandakan, dan menggunakan secara tepat agar kegiatan gereja dapat berlangsung dengan baik (Alawode, 2020).

Berdasarkan uraian tersebut, maka dana gereja harus diatur sedemikian rupa dan rapi, sehingga bisa mencukupi segala keperluan, khususnya untuk operasional gereja. Selain itu dana gereja dapat diinvestasikan sebaik-baiknya sehingga dapat mencukupi semua kebutuhan gereja baik yang varibel cost maupun yang fixed cost. Untuk itu investasi yang alkitabiah dan resiko yang minimal sangatlah diperlukan. Oleh sebab itu gereja sebaiknya mencari jalan untuk menemukan investasi yang sesuai dengan merundingkannya dengan semua pengurus, sehingga akan tercapai keputusan yang tepat.

Sebuah organisasi mempunyai tujuan utama untuk memaksimalkan return on investment (ROI). Namun, belakangan ini tren menunjukkan bahwa investor juga mementingkan investasi yang bertanggung jawab ketika membuat keputusan untuk menanamkan modal (Mercedes Alda, 2019). Sehingga, meskipun organisasi secara umum ingin memaksimalkan ROI, mereka juga sekarang ini mulai mempertimbangkan dampak investasi mereka terhadap lingkungan dan masyarakat.

Dalam berinvestasi, selain bertujuan untuk memaksimalkan keuntungan, kita juga harus memastikan bahwa usaha investasi tersebut sesuai dengan firman Tuhan. Ada lima aspek penting yang perlu diperhatikan dalam hal ini. Pertama, Tujuan gereja melakukan investasi bukan semata-mata mengejar keuntungan tetapi harus dilakukan untuk memuliakan Tuhan, yaitu melakukan investasi dengan pendekatan yang mengakui dan menyadari keterlibatan Tuhan dalam pengelolaan dan tujuan akhir dari investasi tersebut. Kedua, dalam berusaha haruslah jujur dan adil, dan jangan berbuat curang dan tidak adil. Kebenaran dan keadilan merupakan suatu aspek yang sangat penting dalam bekerja. Secara khusus, ditekankan di dalam kitab tersebut bahwa jauh lebih berharga di mata Tuhan walau kita menghasilkan sedikit dalam kebenaran, daripada mempunyai penghasilan yang banyak tapi kita memperolehnya tanpa disertai keadilan. Ketiga, dalam berusaha atau berinvestasi, kita harus teliti dan mengetahui dengan jelas darimana usaha uang itu. Seperti yang ditulis dalam Ulangan 23: 18, kita tidak boleh membawa upah sundal ke dalam rumah Tuhan karena hal itu dianggap kekejian bagi Tuhan. Keempat, dalam berusaha kita harus menghasilkan laba denga cara yang setia dan bertanggung jawab seperti yang diberi lima dan sepuluh mina. Yesus berkata bahwa orang-orang yang setia dalam perkara kecil akan diberikan tanggung jawab dan kepercayaan yang lebih besar lagi dari Tuhan. Hal ini menunjukkan bahwa pekerjaan sekecil apapun, apabila dikerjakan dengan penuh tanggung jawab secara maksimal, akan menghasilkan berkat yang lebih besar untuk orang tersebut. Kelima, dalam berinvestasi, kita tidak boleh menaruh semua investasi dalam satu usaha namun harus melakukan diversifikasi. Hal ini dimaksudkan agar investasi tersebut memiliki resiko yang minimal. Bagaimana pun resiko dalam berinvestasi akan selalu ada, dan kemungkinan ke arah tersebut harus diperkecil dengan cara diversifikasi ini. Tentu hal ini berkaitan juga dengan kondisi dunia yang tidak menentu akibat Covid-19 dan krisis yang terjadi; karena kita tidak pernah mengetahui apa yang akan terjadi di dunia ini.

Dengan memperhatikan dan menganalisa pembahasan diatas maka penulis mencoba memberikan suatu model investasi yang ber-resiko rendah, melibatkan jemaat gereja, seusai dengan visi dan misi gereja. Adapun metodenya terdiri dari tiga aspek penting. Pertama, bendahara dengan persetujuan pendeta dan majelis gereja meng-alokasikan sejumlah dana gereja untuk tujuan investasi sehingga tidak menggangu program kerja gereja. Kedua, gereja membentuk suatu departemen khusus yang menjalankan program investasi sehingga bisa menjalankan secara professional. Departemen ini akan mempunyai staf khusus yang 
akan menangani segi marketing, pengawasan dan pelatihan secara professional. Ketiga, gereja dapat memulai fokus dalam usaha yang melibatkan jemaat gereja dengan sistem bagi hasil.

Berkaitan dengan program-program usaha, ada beberapa hal yang yang dapat dilakukan oleh gereja. Pertama, gereja dapat membuka usaha kantin atau restoran di lingkungan gereja dengan bekerjasama dengan jemaat yang mempunyai keahlian memasak. Kedua, gereja dapat membuka klinik umum dan klinik gigi dengan bekerjasama dengan jemaat yang mempunyai profesi dokter atau dokter gigi dan perawat untuk meningkatkan kesehatan jemaat. Ketiga, gereja dapat memberdayakan jemaat di daerah misi atau daerah minus, dengan kerjasama beternak ayam potong dan sapi yang bertujuan untuk meningkatkan kesejahteraan jemaat. Keempat, gereja dapat juga memberdayakan jemaat di daerah misi, dengan kerjasama pertanian sesuai potensi daerah yang bersangkutan, dengan tujuan untuk meningkatkan kesejahteraan jemaat.

\section{Kesimpulan}

Investasi dana gereja bisa dilakukan sesuai intepretasi dari Alkitab maupun beberapa alasan untuk mencapai visi dan misi gereja. Pengelola keuangan gereja bisa menginvestasikan dana gereja sepengetahuan pimpinan gereja (gembala sidang) dan para majelis gereja (penatua/penilik jemaat). Dalam menginvestasikan dana tersebut harus diperhatikan beberapa hal agar nantinya dapat dipertanggungjawabkan kepada jemaat. Yang pertama sebaiknya resiko haruslah paling minimal bahkan tingkat resiko nol. Kedua, investasi yang melibatkan dan menguntungkan jemaat. Ini bisa terjadi dengan kontrol dan seleksi yang ketat terhadap usaha yang akan dijajaki bersama jemaat. Beberapa cara dalam kontrol, bisa dilakukan dengan manajemen pengelolaan bisnis seperti modal usaha awal dari jemaat, namun untuk tempat dan sarana dari gereja. Hal ini tentu tanpa resiko, namun bisa menguntungkan kedua belah pihak. Ketiga, berdasarkan pembahasan, dapat ditarik suatu kesimpulan bahwa dana gereja bisa diinvestasikan dengan menggunakan dana gereja, dengan memperhatikan resiko terendah dan bukan semata-mata mencari keuntungan uang namun dengan melakukan pendekatan yang mengakui dan menyadari keterlibatan Tuhan dalam pengelolaan dan tujuan akhir dari investasinya agar dapat memuliakan nama Tuhan. Selain itu investasi dana gereja harus dilakukan dengan jujur dan transparan sehingga jemaat mengetahuinya. Diharapkan investasi dana gereja bisa mendukung kemandirian pendanaan gereja, dengan fokus kepada keterlibatan pendayagunaan kemampuan umat gereja demi meningkatan perekonomian dankesejaterahan umat gereja juga.

\section{Referensi}

Adrian, Chris.Dr ( Lecturer in Accounting, M. U. (n.d.). Wawancara langsung.

Aggarwal, R. K., \& Samwick, A. A. (2003). Why do Managers Diversify their Firms? Agency Reconsidered. Journal of Finance, 58(1), 71-118. https://doi.org/10.1111/1540-6261.00519

Alawode, A. O. (2020). The importance and challenges of money in christian missions. HTS Teologiese Studies / Theological Studies, 76(1), 1-5. https://doi.org/10.4102/hts.v76i1.5984

Faizal, A. (2013). Dugaan Korupsi Dana Gereja Rp. 4,7 Triliun, Jemaat saling lapor. Kompas.

Gannon, T. M., \& Schwartz, D. F. (1992). Church Finances in Crisis. Social Compass. https://doi.org/10.1177/003776892039001011

Guy, L. (1997). The interplay of the present and future in the kingdom of God (Luke 19:11-44). Tyndale Bulletin.

Henry, M. (1706). Matthew Henry commentary on the whole Bible (complete). Bible Study Tools.

Enam tokoh gereja Singapura 'bersalah'atas penipuan, (2015).

Luther, M., \& Carruth, W. H. (1897). On trade and usury: an address. 16-35. 
Mercedes Alda. (2019). Corporate sustainability and institutional shareholders: The pressure of social responsible pension funds on environmental firm practices. Business Strategy and the Environment, 28(6), 1060-1071.

Randa, F. (2011). Akuntabilitas Keuangan Dalam Organisasi Keagamaan (Studi Etnografi Pada Gereja Katolik Di Tana Toraja). Jurnal Sistem Informasi Manajemen Dan Akuntansi.

Raya, M. K. G. (2017). Evaluasi Implementasi Pelaporan Keuangan Sebagai Bentuk Akuntabilitas Organisasi Keagamaan (Studi kasus: Gereja Katolik Paroki St. Paulus Miki Salatiga). In Journal of Accounting \& Management Innovation.

Silalahi, J. N. (2019). Paulus Sang Entrepreneur: Pembuat Tenda Sebagai Jembatan Penginjilan. Visio Dei: Jurnal Teologi Kristen. https://doi.org/10.35909/visiodei.v1i1.9

Silvia, J., \& Ansar, M. (2011). Akuntabilitas dalam perspektif gereja protestan (studi fenomenologis pada gereja protestan Indonesia Donggala Jemaat Manunggal Palu. Simposium Nasional Akuntansi XIV Aceh 2011.

Sinay, L. J., Pattireuw, D. S., \& Wattimena, A. Z. (2018). Penentuan Program Dana Pensiun Pada Gereja Protestan Maluku Menggunakan Metode Individual Level Premium. Barekeng: Jurnal Ilmu Matematika Dan Terapan. https://doi.org/10.30598/vol12iss2pp117-126ar624

Susanto, H. (2019). Gereja Yang Berfokus Pada Gerakan Misioner. FIDEI: Jurnal Teologi Sistematika Dan Praktika, 78. https://doi.org/10.34081/fidei.v2i1.23

WF Graham. (1971). The Constructive revolutionary: John Calvin and his socio-economic impact. Richmond (Va.).

yanto Paulus Hermanto. (2021). Kateketika: Bagaimana Gereja Yang Menumbuhkan Rohani \& Meningkatkan Peran Misi Jemaat (1st ed.). pena persada. 